\title{
Boot Spurs: A form of Accessory or a Tool?
}

\author{
Catherine Mathias* \\ Sorbonne Université - Campus Pierre et Marie Curie, FRANCE
}

Submission: January 09, 2018; Published: April 02, 2018

*Corresponding author: Catherine Mathias, Sorbonne Université - Campus Pierre et Marie Curie, FRANCE, Tel: 33 (0)1 44277043 ;

Email: cmathias@mun.ca

\begin{abstract}
For researchers of Art History or Archaeology of the Early Modern Period evidence must be multidisciplinary in order to understand all aspects of culture. Objects which become popular as a costume component can serve as markers for change in culture. This paper will demonstrate the value of one such marker, the boot spur of the 17th century. Examples are taken from an archaeological site in Ferrlyand Newfoundland and the British Museum. Of note here is an additional limitation when using this type of research material and that is the burial environment. Depending on the nature of the material of manufacture even the burial environment will not necessarily tell the whole story as some objects will survive burial and others will not. The boot spur re-surfaces as an important item of dress in the 1900s. One such pair belonging to Sir Sam Hughes, General of Canada's Military in the First World War, shows more detail, because they have not been buried, but are of a similar style.
\end{abstract}

Keywords : Boot spurs; Archaeology; Ferry land

\section{Introduction}

This paper will describe the boot spur of the $17^{\text {th }}$ century and then compare this to one from the 20th century. This element of costume for the 1600 s was both functional and iconic to the wearer. The boot spurs described are from archaeological contexts with one area being at Ferry land Newfoundland and the second having no provenance but has been collected by the British Museum collection. The $17^{\text {th }}$ century boot spur was an expensive piece of horse-related hardware; often with gold or silver gilt on a base metal of brass or iron. Thus few owned this object type and therefore it is rare to find these in the archaeological record. It is also rare to find these objects given that metals do not survive well in the burial environment. Thus the objects presented here are unique within the context of global museum collections. I therefore encourage researchers and students to further explore the genre of boot spurs from the Early Modern Period. Both collections are accessible by the public. The boot spur from the 20th century is accessible to the public via the Victoria County Historical Society.

\section{Metals used for the Boot Spurs found at the $17^{\text {th }}$ century colony in Ferry land}

During the 1600 s, from the perspective of material culture found in the archaeological record, it would appear that iron metal was an important base metal with gold, silver and tin being important metals for surface decoration. For example, boot spurs from the period were largely made of wrought iron as was a small decorative personal item such as snuff boxes. That said if this site represents much of the 1600 s globally then our interpretation of jewellery is very much determined by burial environment as metals and in particular iron metal is susceptible to degradation in most global burial environments. Figures 1-2 shows a range of personal adornment object types found at the Ferry land site. The best type of soil matrix for metal preservation is one which is dry and or drains easily. Thus high sand and loam concentrations are best allowing for drainage of ground water or precipitation. Such an environment is found at the archaeological site in Ferry land Newfoundland. The doublet hook made of iron shown in Figure 3 is one of a few of this object type which has survived. That is why fragile objects (Figures 4,5), not usually found in an archaeological context give a different view to the $17^{\text {th }}$ century simply because they have survived while most have not. This site, being untouched for centuries, provides excellent context for understanding the evolution of material culture for the Early Modern Period. The 20th century spur is made from a copper alloy likely brass and leather.

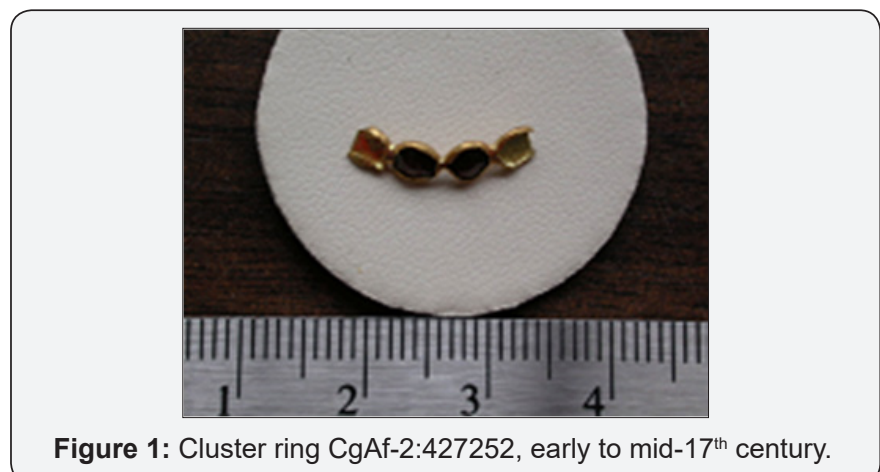



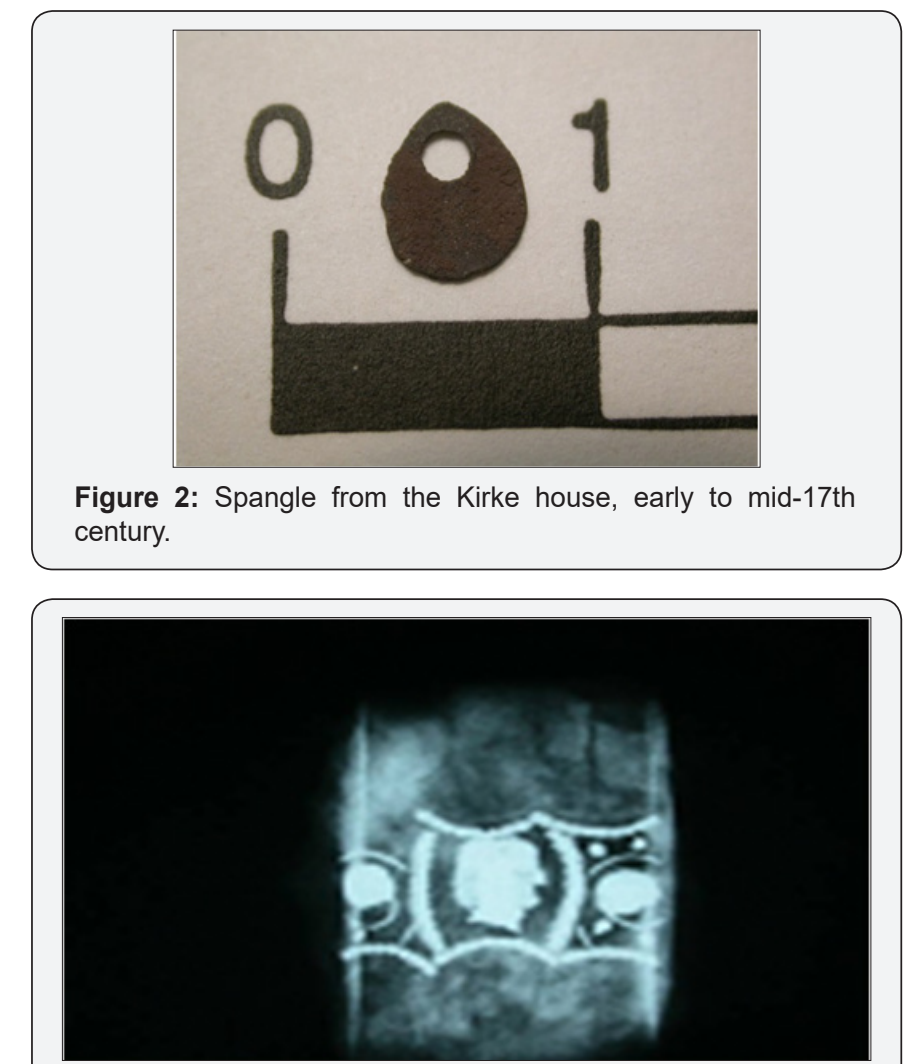

Figure 4 : Snuffbox made of iron and tortoiseshell with pique point, CgAf-2:473691, 1625-1650.

\section{Changes of Style}

One of the most useful aspects of costume to researchers is the change in style over time. This change facilitates the use of these artifact types for dating purposes. If found with a known context in the archaeological burial environment, this object type can aid in the interpretation of the site, for example (Figure 6-8). That said, from the work of art historians we know that costume style changes can be a useful tool for presenting aspects of cultural change and or comment. Thus the style might represent

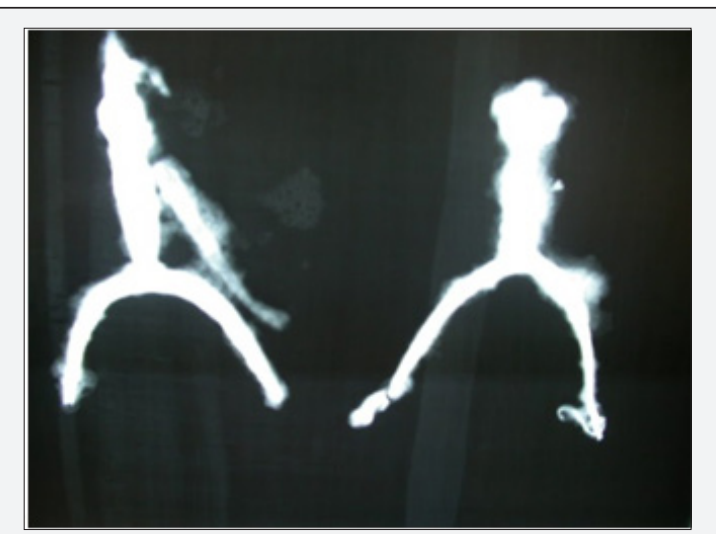

Figure 6 : X-radiographic image of two iron boot spurs from Ferry land, from left to right; CgAf-2:219327, 1640-1696 and CgAf-2:238256, 1640-1696.

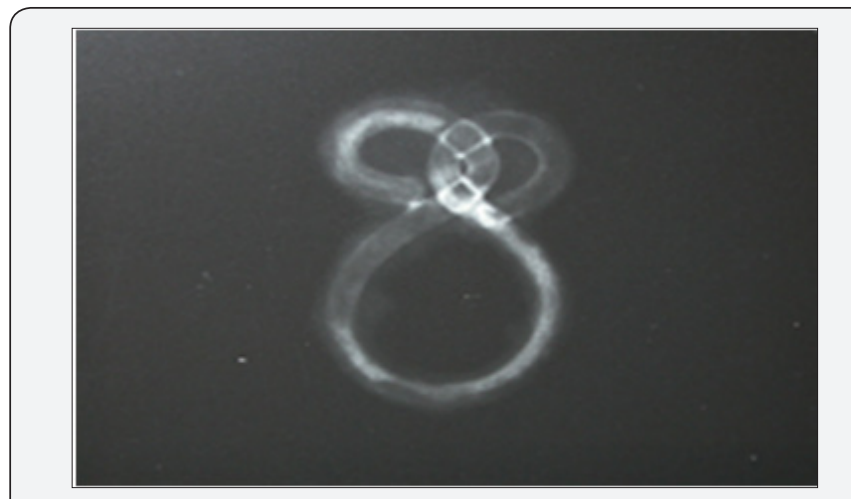

Figure 3 : Iron doublet hook, CgAf-2:473691, 1625-1650.

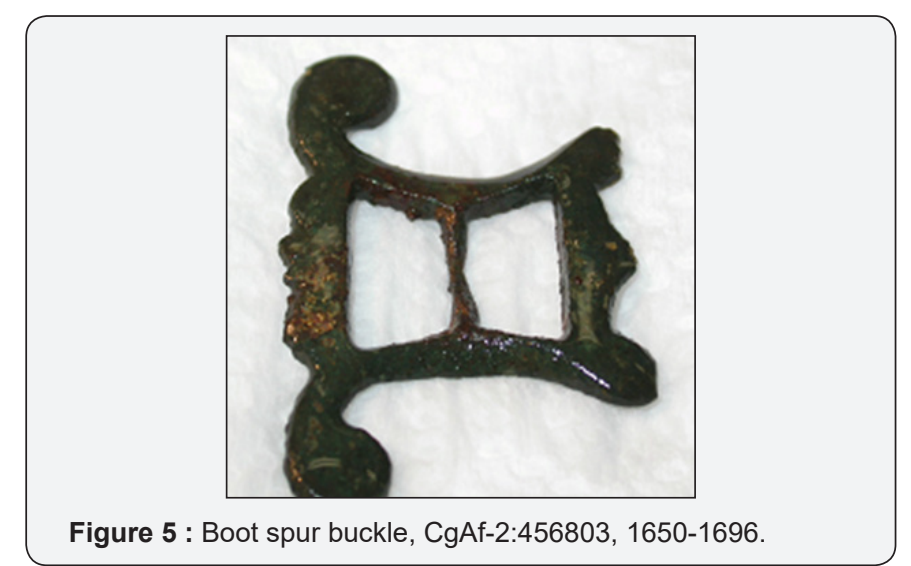

the 1620 s but be used in the 1720 s as a commentary of current cultural change. Similarly because these objects generally have a higher monetary value they are kept and passed along to others thus the context in which they are found can represent other aspects of culture beyond ownership. These facts added to the degradation of the burial environment make any positive identification or matching of artifacts between institutions of great interest. The following description of the archaeological site provides context to the Ferry land boot spurs.

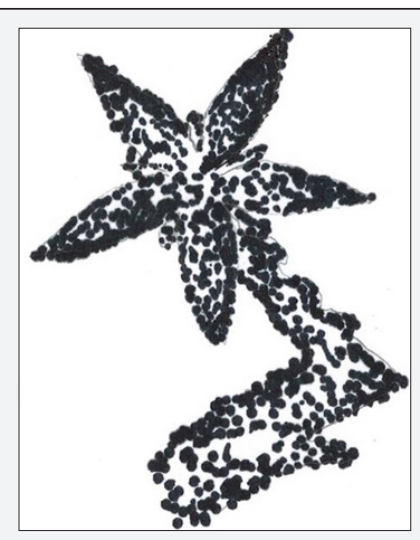

Figure 7 : Sketch of iron rowel boot spur from the British Museum, object number AL 116/417. Note the similarity to object CgAf-2:219327, 1640-1696, from Ferry land Figure 8. 


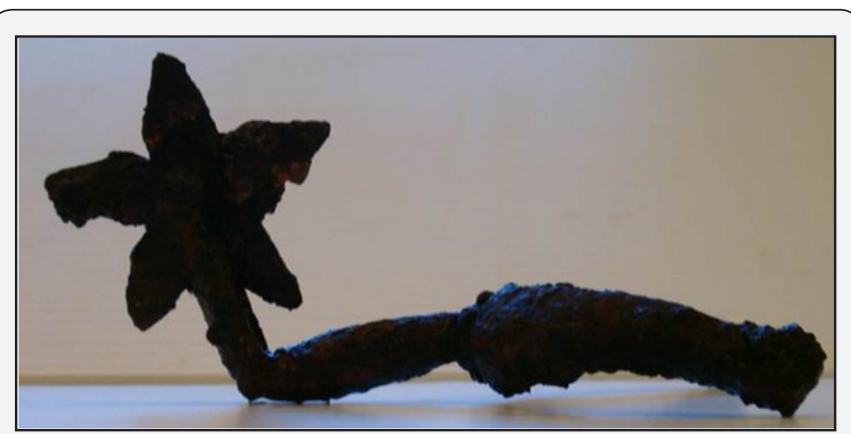

Figure 8 : Rowel spurs CgAf-2:219327, 1640-1696.

\section{The Site}

The areas of excavation relevant to this discussion include three areas of domesticated structures and one of a waterfront warehouse. Costume-related artifacts recovered at the waterfront area are predominantly small finds such as buttons which could have easily been lost from garments worn within this working area of the site. Overall the waterfront appears to be early $17^{\text {th }}$ century. Domestic structures dating to the second half of the $17^{\text {th }}$ century and have been described as houses occupied by residents of the middling class by Nixon and Crompton, respectively, and the associated costume-related material culture generally supports these conclusions $[1,2]$. Though three woollen button holes, found in the area described by Crompton, with silver metal threads, CgAf-2: 78983, are an exception, in that they appear to be early $17^{\text {th }}$ century. These objects are in themselves odd because of the fact that they had been cut out of their original garment for recycling is indicative of a status below that of the gentry. This also could explain the discrepancy in date. Overall though useful costume related objects used to provide context can be extremely problematic. Possibly the most elite of the domestic areas, described by Tuck and Gaulton [3], dates to the second half of the $17^{\text {th }}$ century. This area has supporting luxury goods such as tin-glazed ceramic vessels and terra sigillata earthen wares. Additionally from this area six pipe bowls bearing the initials "DK", and a lead "DK" token were found making researchers believe this to be the residence of Sir David Kirke, proprietor of the "Pool Plantation" from 1638 to 1651 [3]. Fancy objects of costume were found in this area, including two gold rings, silver-plated iron boot spurs, a silver thimble and bodkin, and numerous tin-plated copper pins, and this possibly provide sufficient evidence to confirm that this was the primary Kirke residence in $17^{\text {th }}$ century Ferryland. The boot spur evidence from this area will be used here to compare to boot spurs in the collection of the British Museum. The $20^{\text {th }}$ century boot spur was never buried and stored in domestic enclosures.

Comparison of the Ferry land Boot Spurs with the British Museum Collection

A survey of $311^{\text {th }}$ century boot spurs in the collection of the British Museum, London, was undertaken to identify stylistic changes through the century. Unfortunately, few samples had precise provenance, with the majority simply identified as being from the 1600s. A possible place of manufacture could have been Milan [4]. Stylistic differences in the rowel (rotating star section), terminal (section of loops or hooks allowing boot spur to be attached to boot), and pole (metal shaft onto which the rowel attaches) orientation were identified within the British Museum and Ferry land collections and are summarized in (Table 1a \& 1b).

Table 1a: Stylistic Features of Boot spurs from Ferry land.

\begin{tabular}{|c|c|c|c|c|}
\hline Catalogue Information & Rowel & Terminal & Pole & Heel \\
\hline $\begin{array}{c}\text { CgAf.2.75478 1673, Area C iron-incomplete } \\
\text { 8cm }\end{array}$ & prick thumbtack-sized spike & missing & horizontal & horizontal shaft \\
\hline $\begin{array}{l}\text { CgAf. } 2.23042617 \text { th }-20^{\text {th }} \text { century, Area C } \\
\text { brass/gold gilt cast design with balls } 11 \mathrm{~cm}\end{array}$ & five point $2.5 \mathrm{~cm}$ & two hole & $45^{\circ}$ angle & ball joint at heel \\
\hline $\begin{array}{c}\text { CgAf.2.219327 } 1640-1696, \text { Area F iron- } \\
\text { complete } 13.5 \mathrm{~cm}\end{array}$ & five point $5.38 \mathrm{~cm}$ & missing & $\begin{array}{c}45^{\circ} \text { angle } 4.0 \mathrm{~cm}+4.2 \mathrm{~cm} \text { in } \\
\text { length }\end{array}$ & $\begin{array}{l}\text { horizontal shaft } \\
\text { to pole }\end{array}$ \\
\hline $\begin{array}{c}\text { CgAf.2.238256 } 1640-1696, \text { Area F iron- } \\
\text { complete }\end{array}$ & $\begin{array}{l}\text { prick thumbtack-sized spike } \\
\text { with surrounding petal design }\end{array}$ & $\begin{array}{l}\text { two hole } \\
1.5 \mathrm{~cm}\end{array}$ & $\begin{array}{c}45^{\circ} \text { angle } 3.8 \mathrm{~cm}+3.5 \mathrm{~cm} \text { in } \\
\text { length }\end{array}$ & $\begin{array}{l}\text { horizontal shaft } \\
\text { to pole }\end{array}$ \\
\hline $\begin{array}{c}\text { CgAf-2:477281 Early } 17^{\text {th }} \text { century, Area F iron } \\
\text { cast }\end{array}$ & prick thumbtack-sized spike & two hole & horizontal & $\begin{array}{l}\text { horizontal } \\
\text { extension }\end{array}$ \\
\hline $\begin{array}{c}\text { CgAf.2.431657 Early } 17^{\text {th }} \text { century, Area F iron- } \\
\text { incomplete } 9 \mathrm{~cm}\end{array}$ & prick & two hole & horizontal & $\begin{array}{l}\text { horizontal } \\
\text { extension }\end{array}$ \\
\hline $\begin{array}{c}\text { CgAf.2.446071 } 17 \text { th- } 19^{\text {th }} \text { century, Area G brass } \\
\text { with silver gilt cast }\end{array}$ & rowel five point $5 \mathrm{~cm}$ & missing & missing & missing \\
\hline CgAf-2:472113 1650-1696, Area G copper cast & rowel six point $3.9 \mathrm{~cm}$ & missing & missing & missing \\
\hline
\end{tabular}


Table 1b: Stylistic Features of Boot spurs in the British Museum.

\begin{tabular}{|c|c|c|c|c|}
\hline Catalogue Information & Rowel & Terminal & Pole & Heel \\
\hline AL116/409 iron & $7 \mathrm{~cm}$ - five point & $\begin{array}{l}2 \mathrm{~cm} \text { - two hole rivet }+ \\
\text { buckle }\end{array}$ & vertical cast design $5 \mathrm{~cm}$ & square shaft from pole \\
\hline AL116/463 iron/silver inlay & & & & incised design \\
\hline AL116/417 iron & $7 \mathrm{~cm}$-five point & & vertical cast design $5 \mathrm{~cm}$ & $\begin{array}{l}\text { horizontal extension to } \\
\text { pole }\end{array}$ \\
\hline $\begin{array}{l}\text { AL116/438 } 1630-1670 \text { iron } \\
12.5 \mathrm{~cm} \text { in length }\end{array}$ & $2 \mathrm{~cm}$-twelve points & $1.5 \mathrm{~cm}-$ two hole & horizontal & \\
\hline $\begin{array}{l}\text { AL116/416 } 1620-1660 \text { iron } \\
14 \mathrm{~cm} \text { in length }\end{array}$ & five point & different stud and hook & vertical & $\begin{array}{l}\text { horizontal extension to } \\
\text { pole }\end{array}$ \\
\hline $\begin{array}{l}\text { AL116/457 mid } 17^{\text {th }} \mathrm{C} \text { iron/ } \\
\text { silver gilt } 14 \mathrm{~cm} \text { in length* }\end{array}$ & none & $\begin{array}{l}2.5 \mathrm{~cm} \text {-three hole dome } \\
\text { head on latchet button }\end{array}$ & $45^{\circ}$ angle & $\begin{array}{c}\text { incised design } \\
\text { (BeestonCastle and Rose } \\
\text { Theatre sites) }\end{array}$ \\
\hline $\begin{array}{l}\text { AL116/411 late } 17^{\text {th }}-18^{\text {th }} \mathrm{C} \\
\text { iron } 14 \mathrm{~cm} \text { in length }\end{array}$ & none & $2 \mathrm{~cm}$ - two hole & $45^{\circ}$ angle & \\
\hline AL116/412 $2^{\text {nd }}$ half $17^{\text {th }} C$ iron & $\begin{array}{l}3 \mathrm{~cm} \text {-seven point each } \\
\text { point has three barbs }\end{array}$ & two hole* $3 \mathrm{~cm}$ buckle & & \\
\hline $\begin{array}{l}\text { AL116/434 mid-2nd half } 17^{\text {th }} \\
\text { C iron } 13 \mathrm{~cm}\end{array}$ & none & $3 \mathrm{~cm}$-two hole & horizontal & \\
\hline $\begin{array}{l}\text { AL116/454 1610-1660 brass/ } \\
\text { gilded } 11 \mathrm{~cm} \text { (incomplete) }\end{array}$ & $\begin{array}{c}\text { rowel missing wooden } \\
\text { peg attachment }\end{array}$ & missing & horizontal & $\begin{array}{c}\text { cast design square shaft } \\
\text { attachment }\end{array}$ \\
\hline $\begin{array}{c}\text { 36.9-1.65 LG.65 2nd half } 17^{\text {th }} \\
\text { C brass }\end{array}$ & & & horizontal & $\begin{array}{l}\text { cast design ribbon-like } \\
\text { shaft }\end{array}$ \\
\hline $\begin{array}{l}\text { AL116/408 end } 17^{\text {th }}-1 \text { st half } \\
18^{\text {th }} \mathrm{C} \text { brass } 10 \mathrm{~cm}\end{array}$ & & $1.4 \mathrm{~cm}$-two hole & horizontal $2.5 \mathrm{~cm}$ & stylised grape+trellis \\
\hline $\begin{array}{c}\text { AL116/493 } 1630-1650 \text { brass/ } \\
\text { gold gilt } 15 \mathrm{~cm}\end{array}$ & $5 \mathrm{~cm}$ - five point & $2 \mathrm{~cm}$ - two hole buckle & vertical & $\begin{array}{l}7 \mathrm{~cm} \text { horizontal shaft to } \\
\text { pole }\end{array}$ \\
\hline Catalogue Information & Rowel & Terminal & Pole & Heel \\
\hline AL116/403 brass & missing & three hole & horizontal incised design & $\begin{array}{c}7 \mathrm{~cm} \text { horizontal shaft incised } \\
\text { design ball to pole }\end{array}$ \\
\hline AL116/469 1600-1660 & missing & missing & horizontal & $\begin{array}{c}7 \mathrm{~cm} \text { horizontal shaft incised } \\
\text { design }\end{array}$ \\
\hline AL116/489 brass & missing & 2 hole & vertical incised design & curved \\
\hline $\begin{array}{l}\text { AL116/487 early } 17^{\text {th }} \mathrm{C} \text { brass } / \text { gol } \\
\text { gilt stylised rose in trellis } 14 \mathrm{~cm}\end{array}$ & $\begin{array}{l}\text { seven point }(4 \mathrm{~cm}) \\
\text { star }+ \text { pole }=6 \mathrm{~cm}\end{array}$ & two hole $(1.5 \mathrm{~cm})$ & horizontal & ball \\
\hline $\begin{array}{c}\text { AL116/397 } 1620-1660 \text { rose }+ \\
\text { trellis } 11.5 \mathrm{~cm}\end{array}$ & missing & missing & vertical $5.5 \mathrm{~cm}$ & horizontal shaft to pole \\
\hline $\begin{array}{c}\text { AL166/399 brass rose }+ \text { trellis } \\
\text { similar to } 397\end{array}$ & missing & missing & vertical $3 \mathrm{~cm}$ & horizontal shaft to pole \\
\hline $\begin{array}{c}\text { 1836.9-1.54 LG.54 } 1620-1660 \\
\text { brass } 11 \mathrm{~cm}\end{array}$ & missing & missing & vertical $5.5 \mathrm{~cm}$ & ball attachment \\
\hline $\begin{array}{c}\text { AL116/400 } 1600-1660 \text { brass } \\
12 \mathrm{~cm}^{*}\end{array}$ & missing & 2 hole & $45^{\circ}$ angle $4.5 \mathrm{~cm}$ & $45 \mathrm{E}$ angled shaft to pole \\
\hline Al116/402 1620-1660 brass & missing & missing & $\begin{array}{l}\text { horizontal } 5 \mathrm{~cm} \text { incised } \\
\text { design }\end{array}$ & \\
\hline AL116/404 1630? Brass $11 \mathrm{~cm}$ & missing & two hole incised design & horizontal $2.5 \mathrm{~cm}$ & \\
\hline $\begin{array}{l}\text { AL116/448 mid } 17^{\text {th }} \mathrm{C} \text { brass } \\
12.5 \mathrm{~cm}\end{array}$ & missing & heart-shaped studs & horizontal $3 \mathrm{~cm}$ & \\
\hline AL116/423 brass $12.5 \mathrm{~cm}$ & missing & two hole $1.5 \mathrm{~cm}$ & horizontal & \\
\hline $\begin{array}{c}\text { AL116/502 mid - last half } 17^{\text {th }} \mathrm{C} \\
\text { brass } 12.5 \mathrm{~cm}\end{array}$ & no star & two hole $1.5 \mathrm{~cm}$ & & \\
\hline AL116/420 end $17^{\text {th }} C$ brass $12 \mathrm{cr}$ & no star & $\begin{array}{l}\text { two hole buckle } 3.5 \mathrm{~cm} \\
\text { length }\end{array}$ & vertical & horizontal shaft to pole \\
\hline
\end{tabular}




\section{Global Journal of Archaeology \& Anthropology}

\begin{tabular}{|c|c|c|c|c|}
\hline Catalogue Information & Rowel & Terminal & Pole & Heel \\
\hline AL116/445 1640s brass Beeston Castle 9.5cm & missing & two hole & horizontal & missing \\
\hline AL116/465 1630-60 brass/gold gilt English & missing & $\begin{array}{c}\text { repair on terminal two } \\
\text { hole }\end{array}$ & m \\
\hline
\end{tabular}

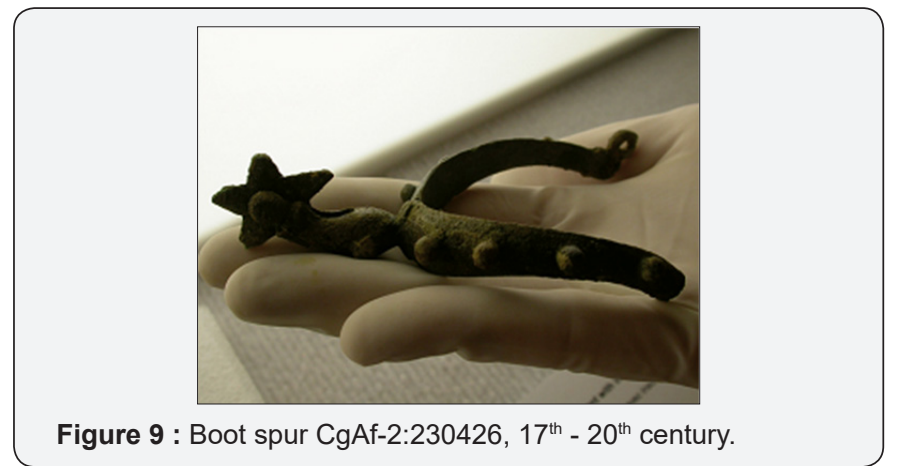

The Ferry land collection holds eight individual boot spurs. Five of these represent either complete or fairly complete boot spurs while three examples are only the rowels. Each of these shows evidence of wear and each was likely discarded because it no longer functioned properly. Each displays stylistic and material variation. The first brass and gold gilt boot spur (CgAf-2:230426), (Figure 9) with its $2.5 \mathrm{~cm}$, five-point rowel resembles British Museum objects AL116/400 and AL116/404. The first British Museum example was assigned a date range of $1600-1660$, while the second probably dates to the 1630 s and certainly fits within the 1600-1650 range. The Ferryland example was found in a deposit associated with the Kirke house (1640s-1696). Ceramic sherds from this midden have also been identified as wares from the first half of the $17^{\text {th }}$ century [5]. The examples identified in the British Museum collection, as well as the archaeological evidence, indicate that this particular boot spur can be assigned a date range of 1600-1660.

Bold text $=$ components of both iron and brass spurs which may match with Ferry land spurs

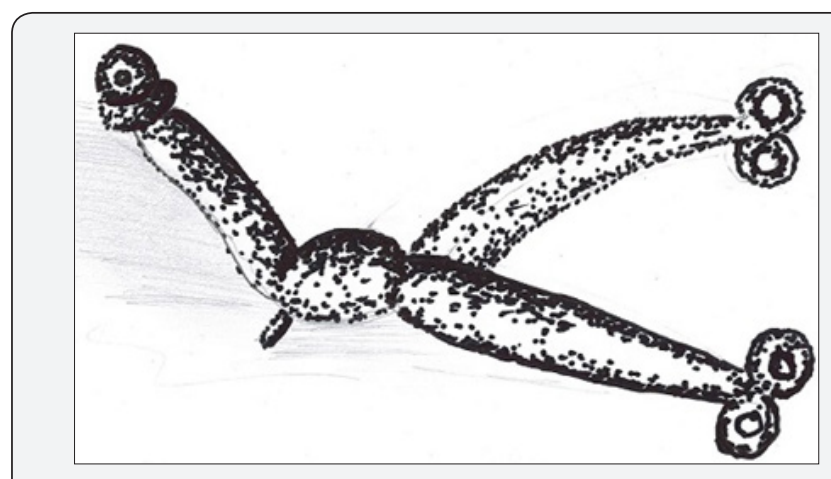

Figure $10:$ An examples of a $17^{\text {th }}$-century iron boot spurs from the British Museum, sketch of AL116/434.

Iron boot spur fragments from Ferryland could match with those from the British Museum as follows (Figure 10). Figure 10 is a sketch of a boot spur from the British Museum showing the terminal ends. X-radiography of artifact CgAf-2:75478 Figure 11 has similar terminal ends. Figure 12-14 shows a prick spur
CgAf-2:238256 which date to the mid- $17^{\text {th }}$ century. These boot spurs resemble boot spurs AL116/411, AL116/434 and AL/463 from the British Museum. Objects AL116/434 and AL116/416 date to the mid-17th century while AL116/411 dates to the late $17^{\text {th }}$ century. British Museum samples AL116/409, AL116/416 and AL116/417 are similar to iron boot spur CgAf-2:219327 (Figures 4-6), dating to the mid- $17^{\text {th }}$ century.

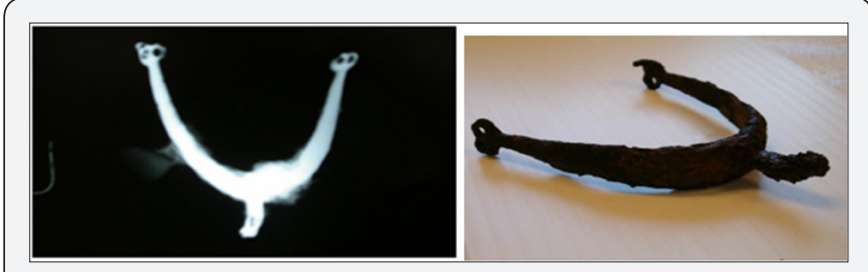

Figure 11 : An x-ray radiograph of prick spur CgAf-2:75478, 1673. Note that the prick spur has 2-hole terminals similar to AL116/434 from the British Museum.

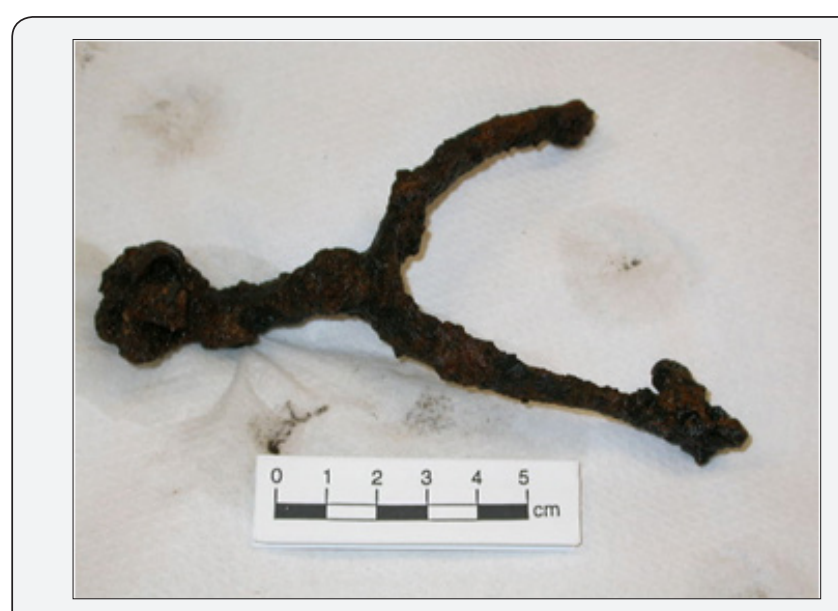

Figure 12 : Prick spur from Ferryland, CgAf-2:238256, 16401696, the Kirke house.

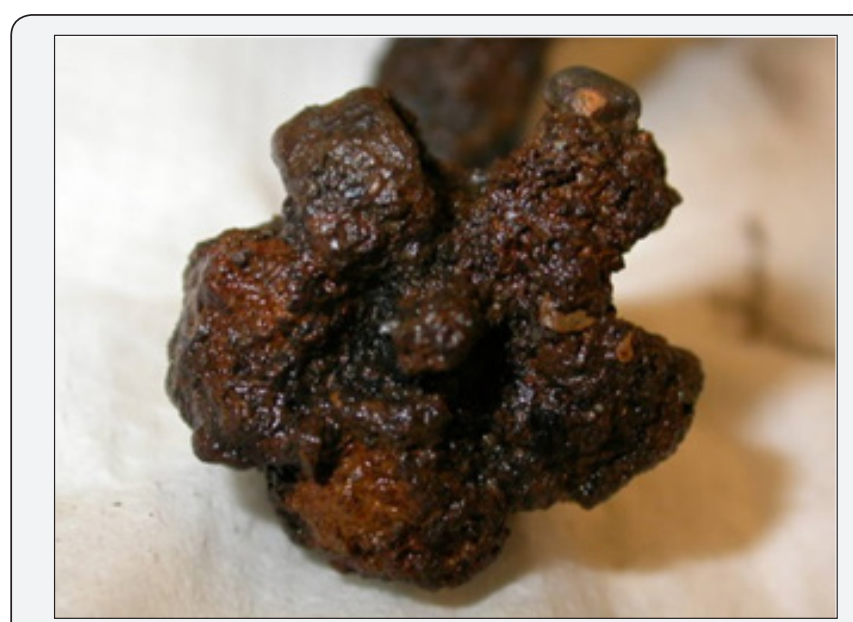

Figure 13 : Prick end for spur CgAf-2:238256, 1640-1696. 


\section{Global Journal of Archaeology \& Anthropology}

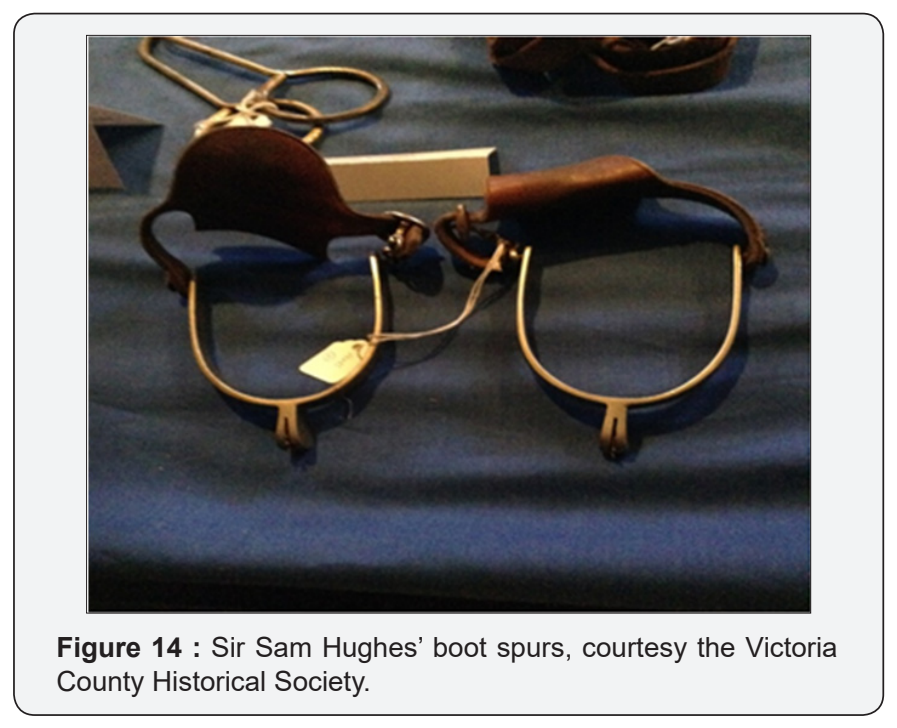

Noël Hume suggests that during the first half of the $17^{\text {th }}$ century boot spurs were mostly made of iron [6]. Brass spurs were also used at this time but tended to be very fancy with elaborate chased design and gold gilt. They had large rowels and elbowed shanks and poles. The most common type of boot spur had a straight shank with a small thumbtack-sized spike or prick instead of a rowel. Based on the boot spurs recovered at Ferryland, it seems likely that object CgAf.2.238256 was made of iron and was used by someone of the middling sort while the fancier brass spur was used by one of the gentry. The iron spur with a five-point rowel was probably covered with silver or gold gilt as fragments of this layer are visible today. The style of this example compares well with those in the British Museum collection which date from the middle to end of the century. The appearance of smaller rowels has been associated with the latter half of the $17^{\text {th }}$ century and early $18^{\text {th }}$ century. The smaller rowel of brass boot spur CgAf-2:230426 (Figure 9) could indicate a late $17^{\text {th }}$ century date; however it resembles boot spurs from the British Museum collection dating to the mid- $17^{\text {th }}$ century. Although based on only a few samples, it appears that boot spurs were worn throughout the $17^{\text {th }}$ century in Ferry land, kept and recycled with changes in fashion.
Though this paper presents an important costume component of the $17^{\text {th }}$ century excavated from known context, further research in this area should include comparisons to both print culture and contemporaneous paintings. The difficulty of using the burial environment for descriptions of culture is that not all materials preserve in the soil matrix. Additionally both paintings and to a lesser extent prints do alter their contemporaneous material culture likely for the purposes of propaganda and education.

\section{Conclusion}

Finally the status of the high boot spur for the $17^{\text {th }}$ century further provides evidence of the site at Ferry land Newfoundland being extremely rich and luxurious. Combined with such material culture as the tin-glazed earthenware, leaded glass, silk velvets, silk damask and finer woolens of the new draperies it is a site worth further research $[7,8]$.

\section{References}

1. Nixon, Douglas (1999) A Seventeenth - Century Planter's House at Ferryland, Newfoundland. Avalon Chronicles (4): 57-95.

2. Crompton, Amanda (2000) A Planter's House at Ferryland, Newfoundland. Avalon Chronicles 5: 1-48.

3. Tuck, James A, Barry Gaulton (2001) Archaeology at Ferryland 19982000. Avalon Chronicles 6: 89-106.

4. Shesgreen, Sean (2002) Images of the Outcast: The Urban Poor in the Cries of London. Rutgers University Press, New Jersey, USA.

5. Stoddart, Eleanor (2000) Seventeenth-Century Tin-Glazed Earthenware from Ferryland. Avalon Chronicles 5: 49-99.

6. Noël Hume, Ivor (1969) A Guide to Artifacts of Colonial America. Random House; New York, USA

7. Mathias Cathy, Elizabeth Moffatt and Alison Murray (2004) Technical Analysis of Textile Remains from a $17^{\text {th }}$ Century English Plantation at Ferryland, Newfoundland and Labrador, Canada. Journal of the Canadian Association for Conservation 29: 26-41.

8. Gaulton, Barry and Cathy Mathias (1998) Portuguese Terra Sigillata Earthenware Discovered at a $17^{\text {th }}$ Century Colonial Site in Ferryland, Newfoundland. Avalon Chronicles 3: 1-18.

\section{Your next submission with Juniper Publishers} will reach you the below assets

- Quality Editorial service

- Swift Peer Review

- Reprints availability

- E-prints Service

- Manuscript Podcast for convenient understanding

- Global attainment for your research

- Manuscript accessibility in different formats

( Pdf, E-pub, Full Text, Audio)

- Unceasing customer service

Track the below URL for one-step submission https://juniperpublishers.com/online-submission.php 